\title{
Paideusis
}

\section{Understanding "Understanding Skills": A Response}

\section{Robin Barrow}

Volume 4, Number 2, 1991

URI: https://id.erudit.org/iderudit/1073383ar

DOI: https://doi.org/10.7202/1073383ar

See table of contents

Publisher(s)

Canadian Philosophy of Education Society

ISSN

0838-4517 (print)

1916-0348 (digital)

Explore this journal

Cite this document

Barrow, R. (1991). Understanding "Understanding Skills": A Response.

Paideusis, 4(2), 39-41. https://doi.org/10.7202/1073383ar

This document is protected by copyright law. Use of the services of Erudit (including reproduction) is subject to its terms and conditions, which can be viewed online.

https://apropos.erudit.org/en/users/policy-on-use/
This article is disseminated and preserved by Érudit.

Érudit is a non-profit inter-university consortium of the Université de Montréal, Université Laval, and the Université du Québec à Montréal. Its mission is to promote and disseminate research.

https://www.erudit.org/en/ 


\section{Understanding "Understanding Skills": A Response}

\section{Robin Barrow}

In responding to Woodhouse's generous review, I am anxious not to appear too defensive. There are, of course, weaknesses in the book, and some of them are well noted by Woodhouse. However, in respect of what appears to be his central concern, it seems to me that he may well mislead potential readers into thinking that I do not recognise (or even that I reject) something that, in fact, I entirely accept. It is quite true that for much of the book I do not engage in "discussion of the kind of questioning required" to make the process of critical inquiry and autonomous thought "come alive" and, indeed, that "Questioning" does not appear in the index. However, the fact that a particular word does not appear in the index obviously should not be construed to mean that the concept is not referred to. So far as the index goes, I should have thought that "autonomy," "brainstorming," "critical thinking," "problem solving," and the like, and above all "inquiry," all of which do have an entry, were enough to indicate that the broad issue of raising questions, challenging, and thinking for oneself was being addressed. Indeed, the whole book is in a way directed to that issue. However, I take Woodhouse's real point to be the rather more substantive and specific one that I seem "oblivious to such pedagogical devices as the importance of asking questions in the process of inquiry." It is unfortunate (indeed, a failure on my part) that I should have given that impression. Not only am I not oblivious to it, I wholeheartedly agree with Woodhouse that it is a crucial aspect of teaching. Indeed, part of the reason that I do not spell it out is that I take it for granted. But the other part, which is of more immediate concern, is that this is not a book about pedagogical practice. My concern was to argue about how we should conceive of what we are trying to achieve and, consequently, what we should be trying to teach.

It is no doubt the case that, in practice, questions relating to what we should teach, how it should be organized, and how it should be taught are closely interrelated. For example, there are ways of teaching history that could negate the very reasons for teaching it in the first place. But that does not mean that at a theoretical level one cannot distinguish such questions and, in fact, it is another part of the argument of this book that that is precisely what we should do: get a clear and sane grip on the question of what we are trying to achieve prior to examining the issue of how best to organise it or teach it. As I say in the only chapter that purports to address pedagogical points, "what is certain is that how one should proceed as a teacher is substantially a function of what one is trying to achieve."

This same line of reasoning relates to Woodhouse's remarks about the curriculum I propose and, more specifically, about the nature of philosophy. Again, I agree with him that there is more to philosophy as a subject than mere detached concern for logic and meaning and that, more particularly, the historical context of a philosopher's work is often crucial to understanding that work. The latter consideration is one of many that leads me to argue so determinedly for the importance of history in schools, for I think that ideally all things need to be examined from a historical perspective amongst others. But it is clear that I have given the impression that I am advocating a curriculum organised in terms of the various subjects I mention. That was certainly not my intention. Just as I 
do not directly have much to say about how to teach, so I do not have much to say about how to structure the curriculum. I go so far as to suggest that these questions, which occupy so much of our time, may, in fact, not be susceptible to definitive and detailed answers, and that, provided our understanding of what we are trying to achieve is secure, it may not much matter which of a wide variety of means we adopt to achieve our ends. But the positive thrust of the book is directed to that question of what we should be trying to achieve. In other words, I do not argue that children ought necessarily to study, say, history, philosophy, and science as separate subjects or as traditionally defined. I argue that our curriculum organisation and pedagogical practice should be such as to lead to a secure understanding of the historical, philosophical, and scientific dimension, and the distinct types of inquiry that are appropriate to each. As I say at one point (and as Woodhouse notes, although, in fact, I would go further than he suggests), it is conceivable that something called a "critical thinking" curriculum could encompass all that I am arguing for. That is to say, it could be organised around topics rather than subjects, and it could be taught in such a way as to engender competence in various disciplines. My point is that, in general, this is not what happens, nor could it happen so long as people continue to think in terms of generic skills and do not recognise that, however one comes by it, if one does not have a grasp of history, an understanding of scientific method, and philosophical acumen, and so on, one cannot solve problems or proceed critically in relation to most important issues in the world.

The only positively odd thing that I find in the review is the reference to my exclusion of French. There may, of course, be independent arguments for teaching students French or some other foreign language, and fairly obviously are (though how persuasive is another matter) in a country such as Canada. But Woodhouse suggests that on my own terms I should have included French since it "can be considered intrinsically worthwhile." But lots of things may be thought to be important, or indeed important for stateable reasons, that are nonetheless not educationally important. My claim was that I was presenting a curriculum "that substantially consists of important subjects and basic and powerful forms of inquiry treated in a critical manner." I do not regard French as a form of inquiry at all, and it is not important in the same way that, say, history is. History, and all the other subjects I mention, are characterised in terms of a body of understanding that deals with a distinctive type or range of questions that have importance for illuminating a wide variety of important issues. I cannot see that being able to speak French in itself has any bearing at all on dealing critically with issues such as the environment, marital relations, or free trade.

To return to more general issues, my guess is that Woodhouse is assuming (and he would not be the first to do this) that when a person speaks in favour of the kind of understanding that is enshrined in the traditional disciplines or subjects, he is also defending traditional curriculum organisation of these subjects and traditional teaching methods (not to mention a host of other even more obviously outrageous traditional values!). But I am not. On the contrary, while broadly welcoming moves away from at least some traditional practices, I am worried about throwing the baby out with the bath water. The baby in this case is the edifice of various bodies of thought which simply cannot, I argue, be lightly dismissed. The human mind is wrongly conceived of as a sophisticated 
machine that engages in various critical processes. The critical processes that the brain is capable of only lead to the development of mind and to the capacity for valuable critical thought when they are nurtured in the context of these powerful traditions of thought. The skill-oriented approach to schooling is appropriate to training animals rather than to educating human animals. 